\title{
Iwona Pomianek*
}

\section{CHARAKTERYSTYKA POTENCJALU GOSPODARCZEGO ORAZ PRZESTRZENNYCH ZRÓŻNICOWAŃ ROZWOJOWYCH GMIN WIEJSKICH WOJEWÓDZTWA LUBELSKIEGO}

\begin{abstract}
Streszczenie. W opracowaniu przedstawiono charakterystykę potencjału gospodarczego jednostek terytorialnych na poziomie LAU-2. Analizą objęto 170 gmin wiejskich województwa lubelskiego. Oparty na ośmiu zmiennych miernik taksonomiczny Hellwiga umożliwił pogrupowanie gmin według poziomu rozwoju gospodarczego. Wyodrębniono 29 gmin jako relatywnie wysoko rozwiniętych oraz 22 gminy o niskim poziomie rozwoju. Jednostki o wysokim poziomie rozwoju były rozmieszczone przede wszystkim w powiatach: bialskim, lubelskim, łukowskim i łęczyńskim. Najsłabsze gminy natomiast koncentrowały się w powiatach: janowskim, zamojskim oraz lubelskim. Można zauważyć, że położenie geograficzne gmin wiejskich w powiecie lubelskim ma istotny wpływ na ich zróżnicowanie rozwojowe. Wysoki poziom rozwoju reprezentowały gminy okalające stolicę województwa - Lublin, natomiast gminy położone peryferyjnie - zostały zakwalifikowane do grupy najsłabszych.
\end{abstract}

Słowa kluczowe: rozwój gospodarczy, potencjał ekonomiczny, obszary wiejskie, Polska Wschodnia

JEL: O15, O18, R11, R51

\section{WPROWADZENIE}

Potencjał regionu, będący wynikiem kombinacji lokalnych uwarunkowań, określa jego możliwości i kierunki rozwoju (Milczarek 2005a, Krakowiak-Bal 2006, Reichel 2003). W literaturze można spotkać liczne kategorie potencjału rozwojowego. Na przykład Milczarek (2005a, 2005b) wyróżnia potencjał: geograficzno-demograficzny, ekonomiczny, społeczny, naukowo-technologiczny oraz militarny. Podobnie Kiniorska (2014) wyodrębnia trzy jego rodzaje: demograficzny, gospodarczy i infrastrukturalny. Z kolei Szlachta i inni (2009) dzielą wskaźniki związane z potencjałem na trzy kategorie: zamożność, nowoczesność i konkurencyjność jednostki terytorialnej. Wyodrębnione natomiast przez Wójcika (2011) składowe potencjału rozwojowego opierają się na następujących czynnikach: infrastrukturalnych, demograficznych, edukacyjnych, kulturowych oraz aktywności

*Dr inż. nauk ekonomicznych, Szkoła Główna Gospodarstwa Wiejskiego w Warszawie, iwona pomianek@sggw.pl 
lokalnych samorządów i społeczności. Zbliżony podział przyjmuje Kalinowski (2007), rozpatrując potencjał rozwojowy w pięciu wymiarach: gospodarczym, infrastrukturalnym, społecznym, jakości życia oraz funkcjonowania samorządów.

\section{CEL I METODA}

Celem opracowania jest charakterystyka elementów potencjału gospodarczego gmin wiejskich województwa lubelskiego oraz ocena przestrzennego zróżnicowania rozwojowego tych gmin.

Przy zastosowaniu metody wzorca rozwoju Hellwiga (Hellwig 1986) skonstruowano ranking, który umożliwia podział gmin wiejskich województwa lubelskiego na grupy pod względem poziomu rozwoju gospodarczego. Miernik przyjmuje wartości z przedziału $[0,1]$. Im bardziej wartości cech danej gminy są zbliżone do wzorca, tym poziom jej rozwoju jest wyższy, a im bardziej oddalone - tym niższy. Do klasyfikacji gmin wykorzystano dwa parametry miernika taksonomicznego, tj. średnią arytmetyczną i odchylenie standardowe. Wyodrębniono następujące przedziały:

- klasa 1 (poziom wysoki) $d_{i}>\bar{d}_{i}+s_{d_{i}}$

- klasa 2 (poziom średni) $\bar{d}_{i}-s_{d_{i}} \leq d_{i} \leq \bar{d}_{i}+s_{d_{i}}$

- klasa 3 (poziom niski) $d_{i}<\bar{d}_{i}-s_{d_{i}}$

gdzie: $d_{\mathrm{i}}-$ wartość miernika syntetycznego obliczonego metodą wzorca rozwoju Hellwiga, $\bar{d}_{i}$ - średnia arytmetyczna cechy $d_{\mathrm{i}}$, $s_{d_{i}}$ - odchylenie standardowe cechy $d_{i}$.

Diagnozą objęto 170 gmin wiejskich województwa lubelskiego. Do charakterystyki analizowanego obszaru oraz do konstrukcji miernika syntetycznego wykorzystano dane z Banku Danych Lokalnych Głównego Urzędu Statystycznego.

\section{CHARAKTERYSTYKA POTENCJALU GOSPODARCZEGO GMIN WIEJSKICH WOJEWÓDZTWA LUBELSKIEGO}

Województwo lubelskie, jedno z pięciu zaliczanych do Polski Wschodniej, zajmuje ponad 25 tys. $\mathrm{km}^{2}$ powierzchni (tj. $8 \%$ powierzchni kraju) i co do wielkości plasuje się na trzecim miejscu (po mazowieckim i wielkopolskim). Od północy sąsiaduje z województwem podlaskim, od zachodu z mazowieckim, od południa ze świętokrzyskim i podkarpackim, natomiast od wschodu - z Ukrainą i Białorusią. Wschodnia granica województwa, wyznaczona naturalnie przez rzekę Bug, stanowi także zewnętrzną granicę Unii Europejskiej. Całe województwo wraz z obwodem 
brzeskim na Białorusi, obwodem wołyńskim oraz fragmentem obwodu lwowskiego na Ukrainie, należy do Związku Transgranicznego Euroregion Bug.

Administracyjnie województwo lubelskie podzielone jest na jest cztery podregiony: bialski, lubelski, puławski i chełmsko-zamojski. W granicach województwa wyodrębniono dwadzieścia powiatów ziemskich oraz cztery miasta na prawach powiatu (Lublin, Biała Podlaska, Chełm i Zamość). W ramach powiatów funkcjonuje 213 gmin, w tym 20 miejskich, 23 miejsko-wiejskie i 170 wiejskich ${ }^{1}$. Ponad połowa gmin wiejskich województwa lubelskiego jest skoncentrowana w siedmiu powiatach: bialskim, chełmskim, lubelskim, zamojskim, lubartowskim, tomaszowskim i biłgorajskim. Największe udziały gmin wiejskich w strukturze powiatu charakteryzują powiaty: chełmski (93\%), krasnostawski (90\%) i bialski (89\%).

Do ważniejszych szlaków drogowych przebiegających przez województwo lubelskie należy zaliczyć:

- DK 2 (granica państwa - Świecko - Pniewy - Poznań - Konin - Warszawa - Siedlce - Terespol - granica państwa),

- DK 12 (granica państwa - Błaszki - Sieradz - Łask - Piotrków Trybunalski - Sulejów - Opoczno - Radom - Zwoleń - Puławy - Kurów - Lublin - Piaski - Chełm - Dorohusk - granica państwa),

- DK 17 (Warszawa - Garwolin - Ryki - Kurów - Lublin - Piaski - Krasnystaw - Zamość - Tomaszów Lubelski - Hrebenne - granica państwa),

- DK 19 (granica państwa - Kuźnica - Białystok - Siemiatycze - Międzyrzec Podlaski - Kock - Lubartów - Lublin - Kraśnik - Janów Lubelski - Nisko - Rzeszów),

- DK 48 (Tomaszów Mazowiecki - Białobrzegi - Głowaczów - Kozienice - Nowe Słowiki - Sieciechów - Opactwo - Dęblin - Moszczanka - Kock),

- DK 63 (granica państwa - Węgorzewo - Giżycko - Pisz - Łomża - Zambrów - Sokołów Podlaski - Siedlce - Łuków - Radzyń Podlaski - Wisznice - Sławatycze - granica państwa),

- DK 68 (granica państwa - Kukuryki - Wólka Dobryńska),

- DK 74 (Sulejów - Żarnów - Kielce - Opatów - Ożarów - Annopol - Kraśnik - Janów Lubelski - Frampol - Gorajec - Szczebrzeszyn - Zamość - Hrubieszów - Zosin - granica państwa),

- DK 76 (Wilga - Garwolin - Stoczek Łukowski - Łuków),

- DK 82 (Lublin - Cyców - Włodawa - granica państwa).

Sieć dróg krajowych uzupełniają drogi wojewódzkie (prawie 2,2 tys. km), powiatowe i gminne (rysunek 1). W 2013 roku na $100 \mathrm{~km}^{2}$ przypadało w województwie lubelskim 84,5 km dróg o twardej nawierzchni (w tym 74,6 km dróg zamiejskich; $0,2 \mathrm{~km}$ dróg ekspresowych i autostrad). W tym samym czasie wskaźnik krajowy pozostawał na poziomie 91,2 km (72,6 km dróg zamiejskich; 0,7 km dróg ekspresowych i autostrad).

\footnotetext{
${ }^{1}$ Wg stanu na dzień 31.12.2014, dane BDL GUS.
} 


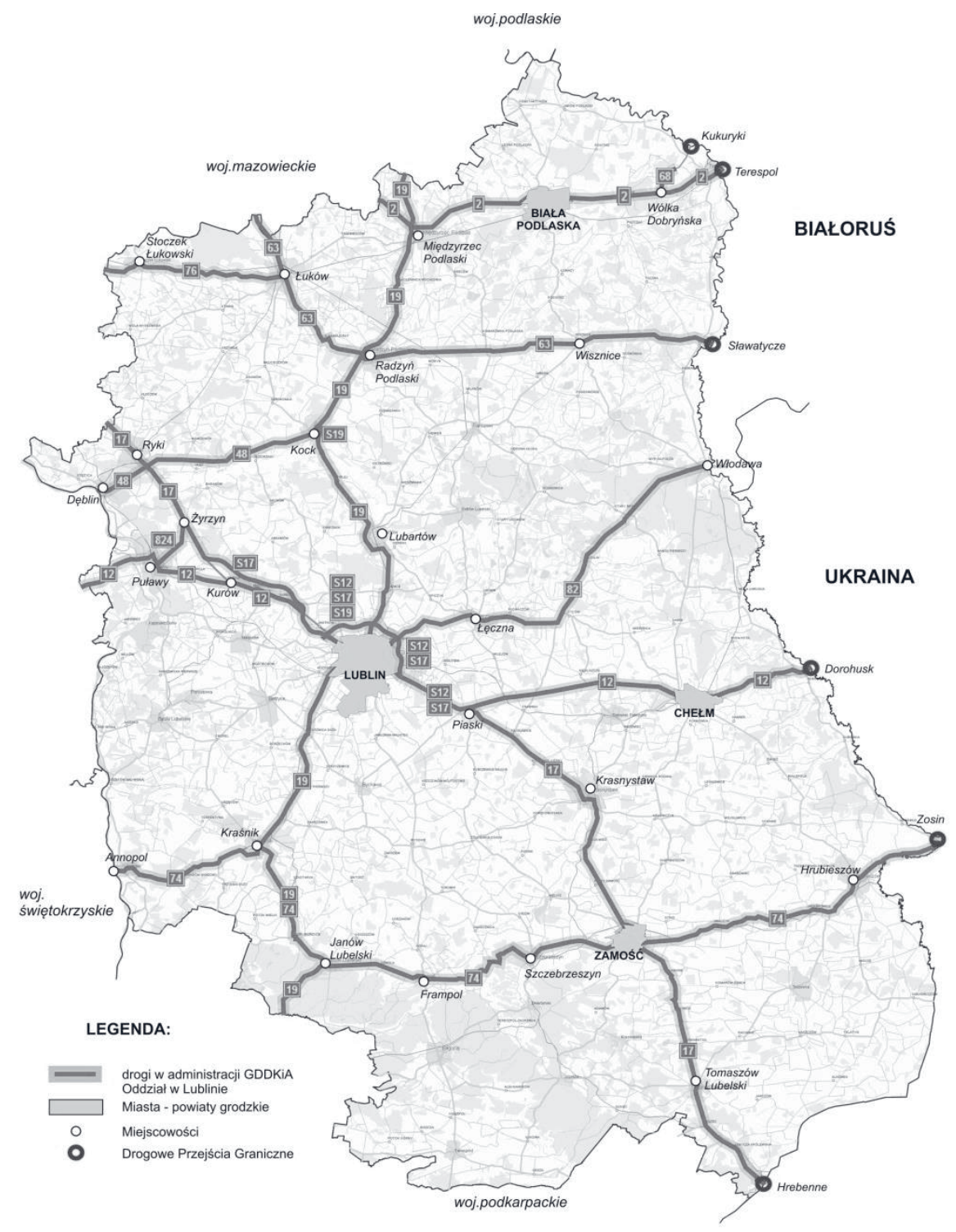

Rysunek 1. Główne szlaki komunikacyjne w województwie lubelskim (stan na 31.03.2015)

Źródło: Generalna Dyrekcja Dróg Krajowych i Autostrad (2015).

Odległość czasowa dojazdu samochodem między Lublinem a przejściem granicznym w Terespolu (z Białorusią) oraz między Lublinem a przejściem granicznym w Hrebennem (z Ukrainą) przekracza 150 minut. Duże znaczenie odgrywają ośrodki subregionalne, takie jak Biała Podlaska, Chełm, Zamość, Tomaszów 
Lubelski, Kraśnik czy Biłgoraj (rysunek 2). W badaniach nad dostępnością komunikacyjną obszarów wiejskich do miast o minimum 50 tys. mieszkańców, obejmujących wszystkie podregiony (NUTS-3) UE-27 (Dijkstra, Poelman 2008), zakwalifikowano część województwa lubelskiego - tj. podregion bialski, jako jedyny w Polsce, do najsłabszej grupy, tj. do wiejskich regionów oddalonych. W tej samej kategorii umieszczono także m.in. podregiony północne: Upper Norrland (Szwecja) i Laponia (Finlandia).

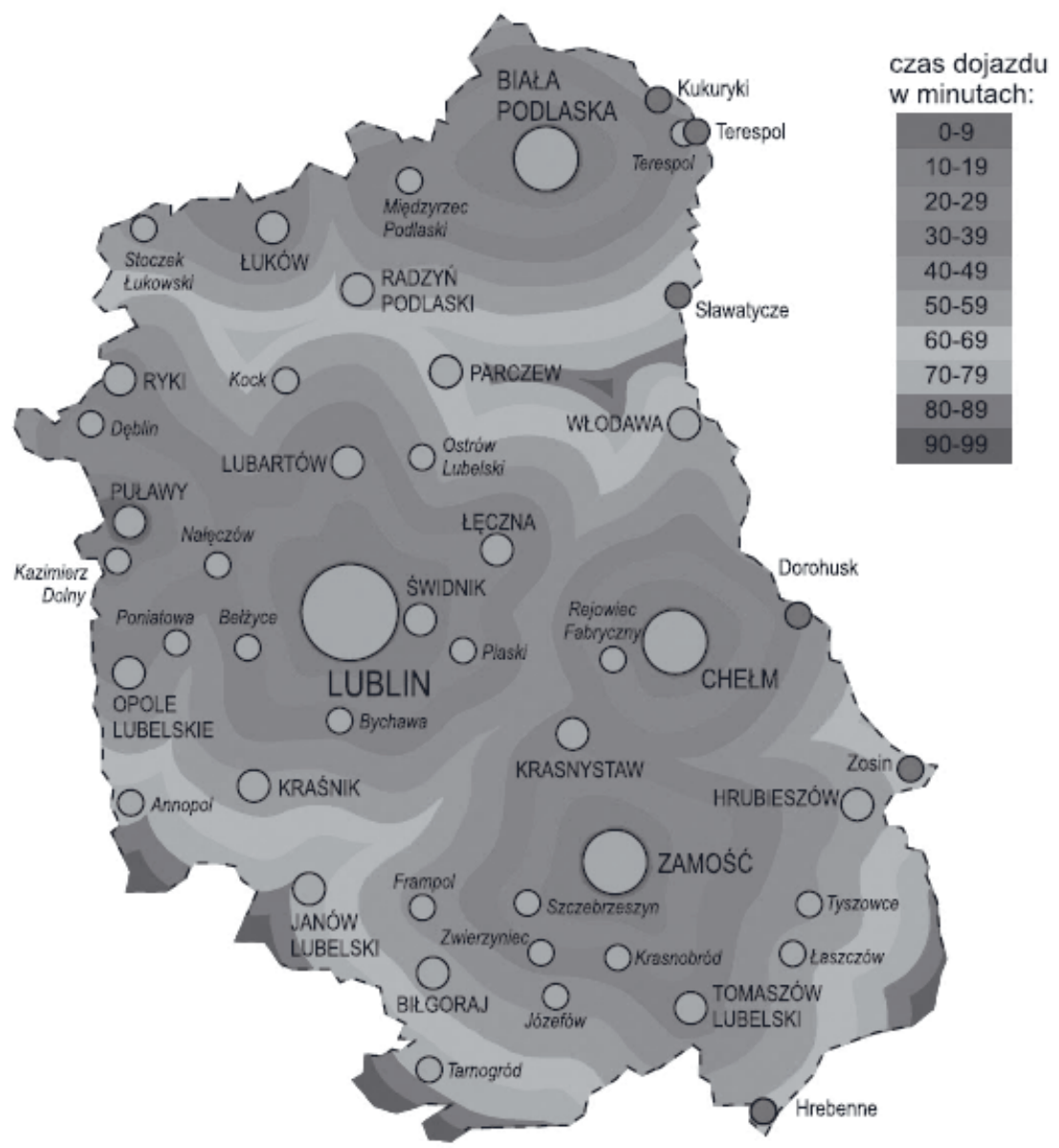

Rysunek 2. Średni czas dojazdu do najbliższego miasta pełniącego ważne funkcje usługowe o znaczeniu subregionalnym

Źródło: Jakubowski 2011: 128. 
Dostępność czasowa i połączenia komunikacyjne są bardzo ważne z punktu widzenia przedsiębiorców (pracodawców) oraz pracowników. Jak wynika z rysunku 3, średnia liczba podmiotów gospodarczych w gminach wiejskich, zarejestrowanych w REGON w przeliczeniu na 1000 mieszkańców, na poziomie krajowym wynosiła 73,5. Analogiczna wartość dla województwa lubelskiego pozostawała na poziomie znacznie niższym i wynosiła 52,2. Powyżej tego poziomu znalazły się gminy wiejskie z powiatów: lubelskiego (69), puławskiego $(63,6)$, łukowskiego $(55,9)$, świdnickiego $(55,3)$, biłgorajskiego $(54,1)$, włodawskiego $(53,5)$, parczewskiego $(53,4)$ i tomaszowskiego $(52,9)$. Najniższe wartości wskaźnika przedsiębiorczości zanotowano w powiatach: chełmskim $(43,8)$ i krasnostawskim $(43,7)$.

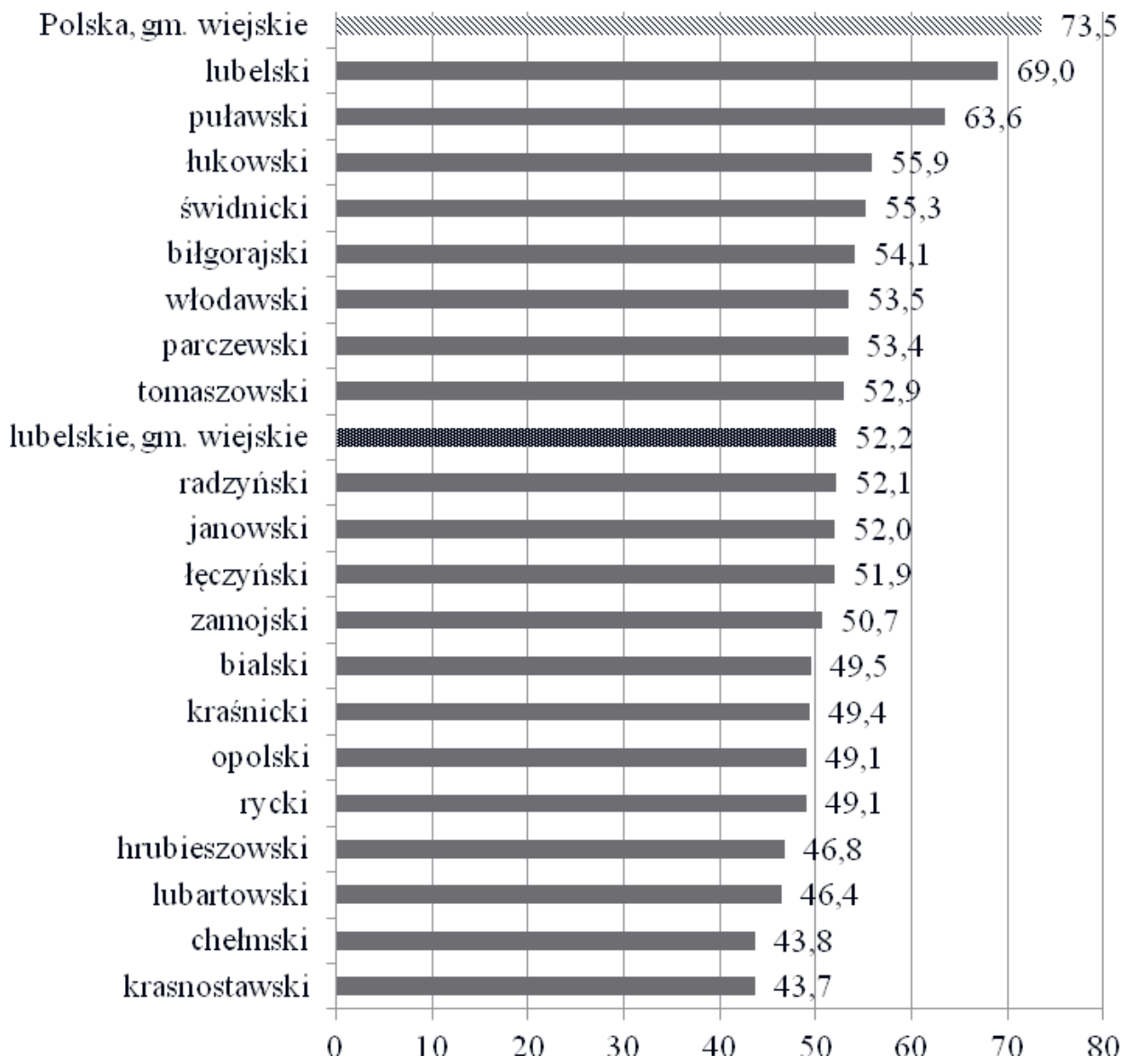

Rysunek 3. Liczba podmiotów gospodarczych zarejestrowanych w REGON na 1000 mieszkańców w gminach wiejskich według powiatów w $2014 \mathrm{r}$.

Źródło: opracowanie własne na podstawie danych BDL GUS. 
W 2014 roku przeciętnie na 1000 mieszkańców w wieku produkcyjnym w gminach wiejskich woj. lubelskiego działalność gospodarczą prowadziło nieco powyżej 6 osób, natomiast wg danych dla wszystkich polskich gmin wiejskich - ponad 9 osób. Relatywnie wysoki poziom aktywności gospodarczej mieszkańców gmin wiejskich (rysunek 4) cechował powiaty: lubelski $(8,9)$, puławski $(7,8)$, łukowski $(7,7)$, biłgorajski $(7)$, janowski $(6,9)$, świdnicki i radzyński (po 6,8$)$. Na końcu listy ponownie znalazły się powiaty: krasnostawski $(5,5)$ oraz chełmski $(5,2)$.

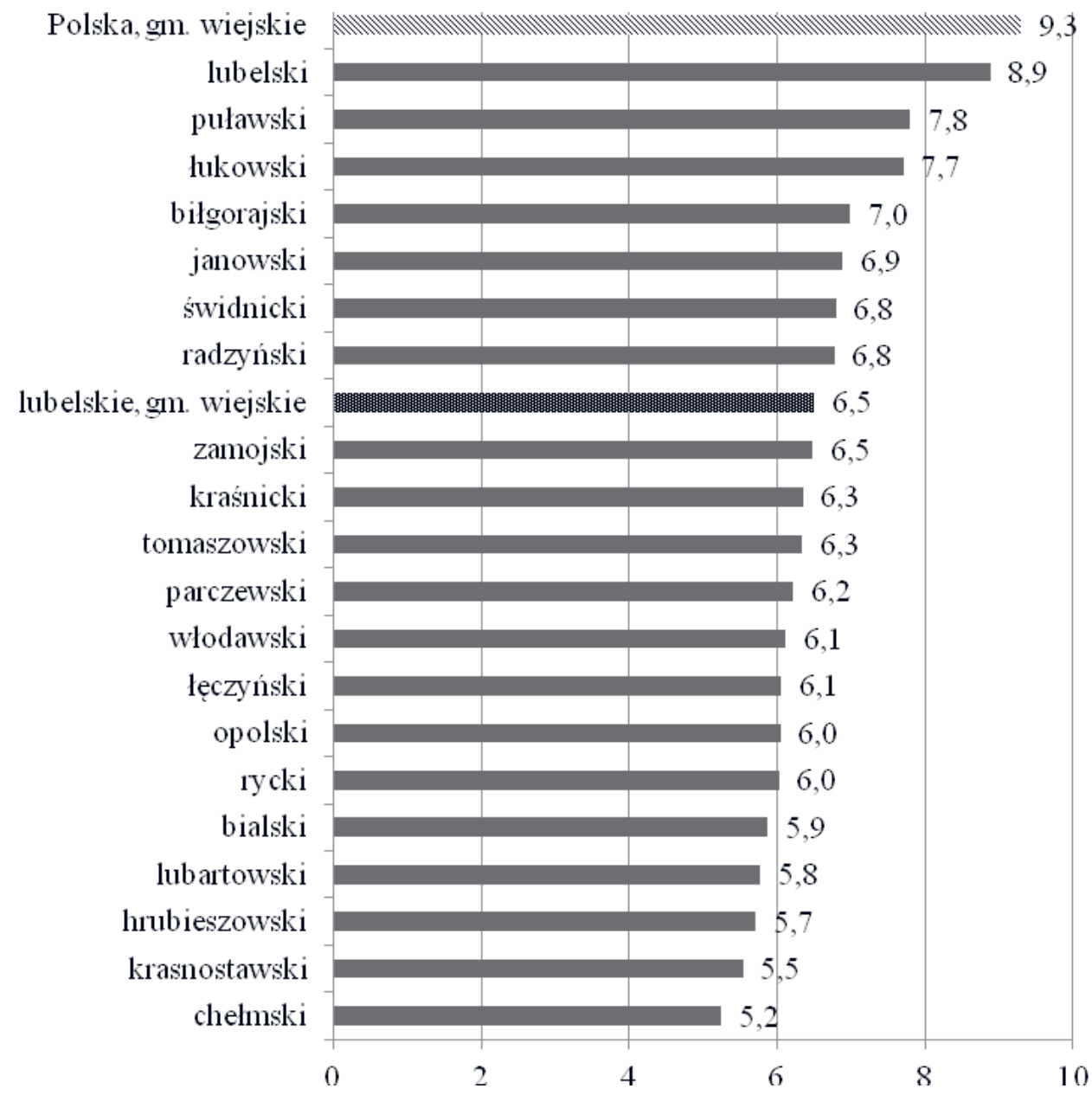

Rysunek 4. Osoby fizyczne prowadzące działalność gospodarczą na 1000 mieszkańców w wieku produkcyjnym w gminach wiejskich według powiatów w 2014 r.

Źródło: opracowanie własne na podstawie danych BDL GUS. 
W 2014 roku najniższe udziały bezrobotnych zarejestrowanych w gminach wiejskich charakteryzowały powiaty: biłgorajski (6\%), łęczyński i lubelski (po 6,4\%), łukowski $(7,2 \%)$ oraz puławski $(7,7 \%)$. Średnia wartość tego wskaźnika w gminach wiejskich w Polsce wynosiła $8,6 \%$, natomiast w województwie lubelskim 9,4\%. Najsłabiej wypadły gminy wiejskie w powiatach: chełmskim $(11,3 \%)$, krasnostawskim $(11,4 \%)$, hrubieszowskim $(13,1 \%)$ i włodawskim (aż 14,9\%). Szczegóły przedstawiono na rysunku 5.

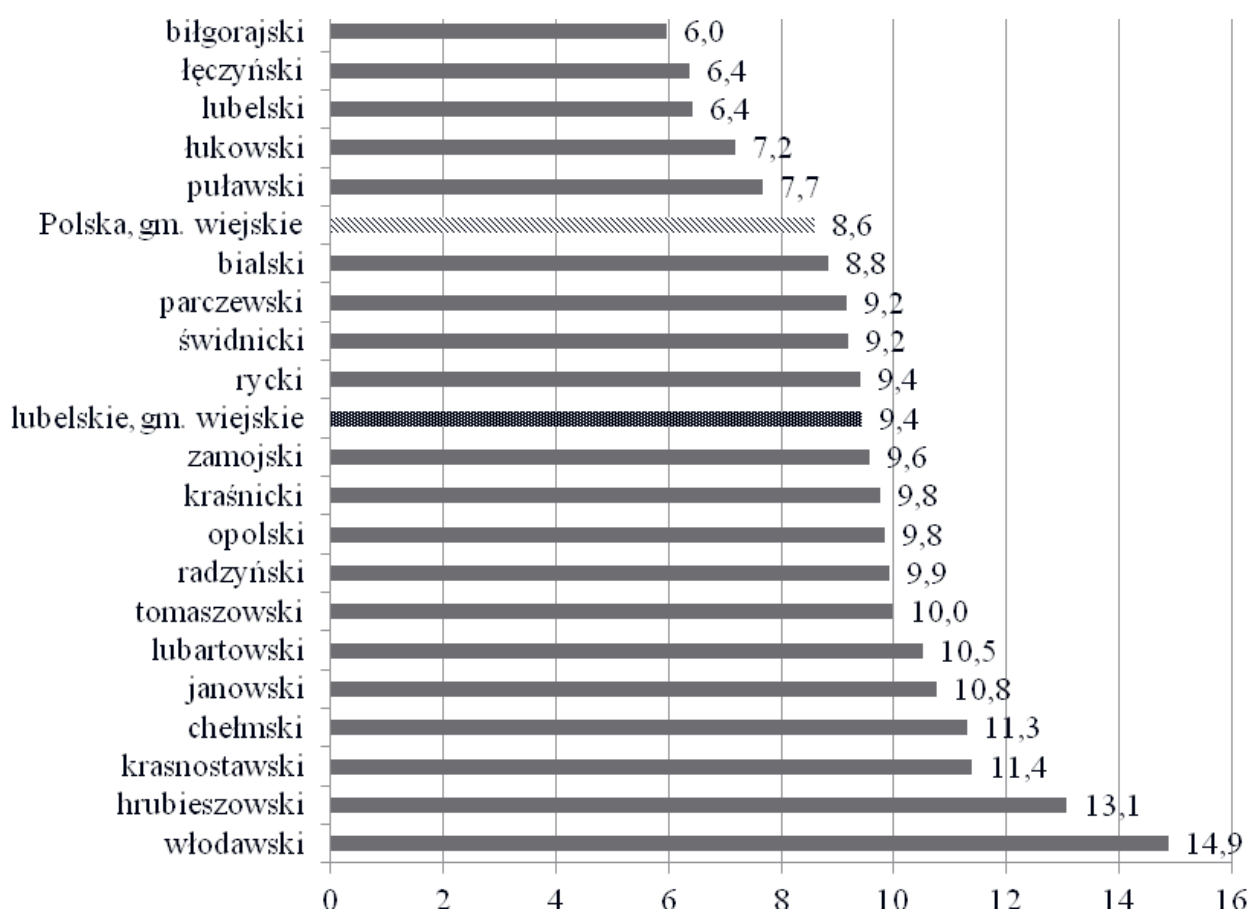

Rysunek 5. Udział bezrobotnych zarejestrowanych wśród ludności w wieku produkcyjnym w gminach wiejskich według powiatów w 2014 r. (\%)

Źródło: opracowanie własne na podstawie danych BDL GUS.

Istotnym czynnikiem informującym o poziomie rozwoju gospodarczego jest infrastruktura techniczna. Według Kudłacza (1999: 52), decyduje ona o atrakcyjności lokalizacyjnej obszaru gminy, oddziałuje na produktywność czynników wytwórczych oraz na poziom życia mieszkańców. W Banku Danych Lokalnych nie są gromadzone aktualne dane dotyczące jakości dróg na poziomie gmin, stąd też zastosowanie takiego wskaźnika nie było możliwe. Analizie poddano stopień wykorzystania sieci wodociągowej oraz 
kanalizacyjnej wg stanu na 31.12.2013². Wykorzystanie sieci wodociągowej w gminach wiejskich województwa lubelskiego, podobnie jak w przypadku poprzednich wskaźników, wypadało słabiej na tle średniej krajowej. Jednakże w aż dziewięciu powiatach (biłgorajskim, lubartowskim, łukowskim, łęczyńskim, świdnickim, opolskim, parczewskim, krasnostawskim oraz puławskim) udział mieszkańców korzystających z sieci wodociągowej przewyższał średnią krajową (76,7\%) i wahał się od 77,4\% do 89,2\% (rysunek 6). Udziały poniżej $50 \%$ zanotowano w powiatach: hrubieszowskim i zamojskim.

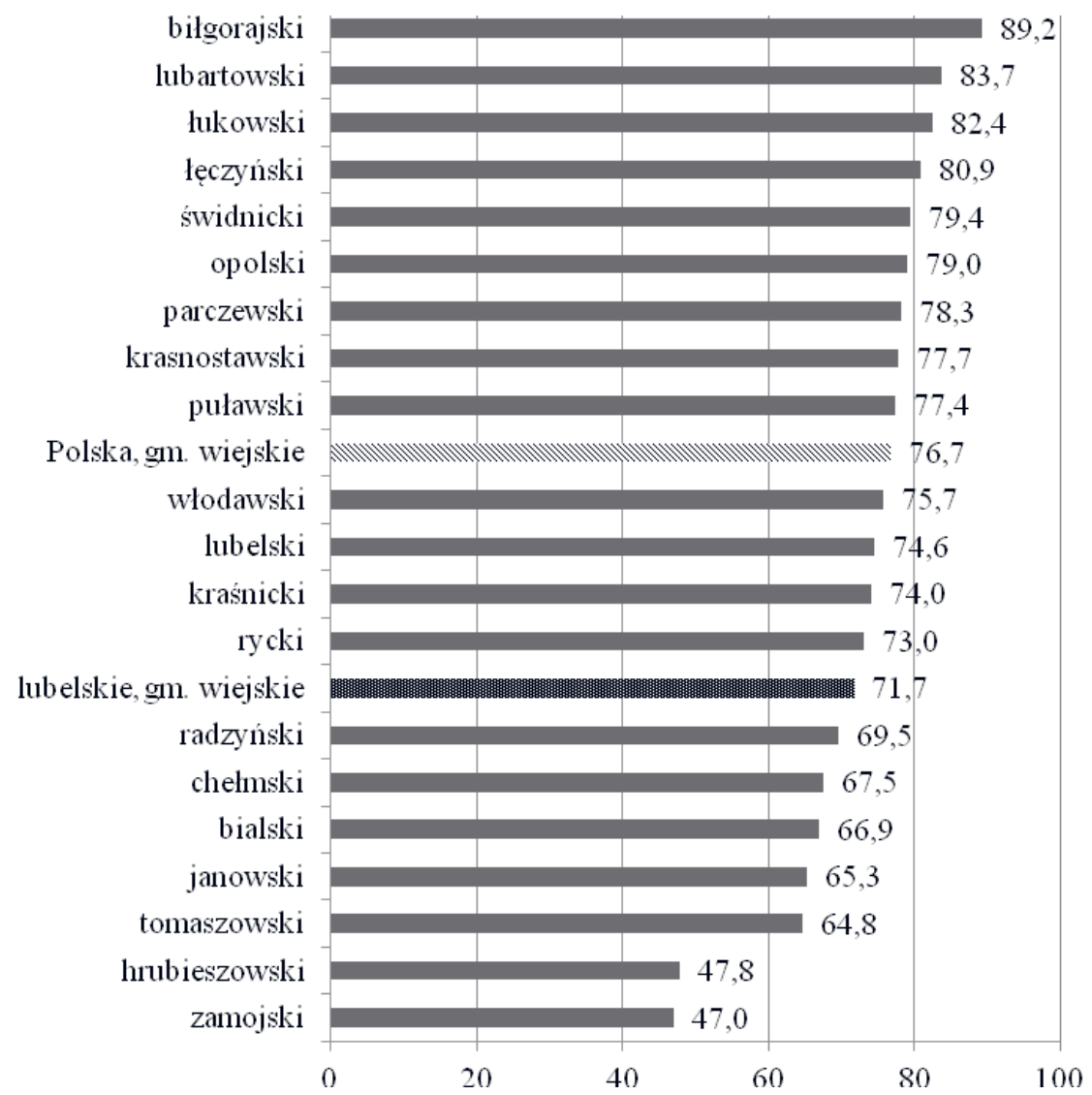

Rysunek 6. Udział mieszkańców korzystających z sieci wodociągowej w ogólnej liczbie ludności w gminach wiejskich według powiatów w 2013 r. (\%)

Źródło: opracowanie własne na podstawie danych BDL GUS.

${ }^{2}$ Do dn. 31.07.2015 nie były dostępne dane za rok 2014 dla następujących cech: udział mieszkańców korzystających z sieci wodociągowej, udział mieszkańców korzystających z sieci kanalizacyjnej oraz powierzchnia użytkowa mieszkań w przeliczeniu na 1 mieszkańca - stąd też analizie poddano dane za rok 2013. 
Udział mieszkańców gmin wiejskich korzystających z sieci kanalizacyjnej (rysunek 7) utrzymywał się na niższym poziomie w porównaniu ze średnią krajową (32,8\%), z wyjątkiem powiatu biłgorajskiego (41,9\%). Przeciętna wartość wskaźnika dla województwa lubelskiego wynosiła 19,1\%, a najsłabiej w porównaniu wypadły cztery powiaty: lubelski $(9,9 \%)$, opolski $(8,1 \%)$, zamojski $(4,6 \%)$ oraz janowski (jedynie $0,1 \%$ ).

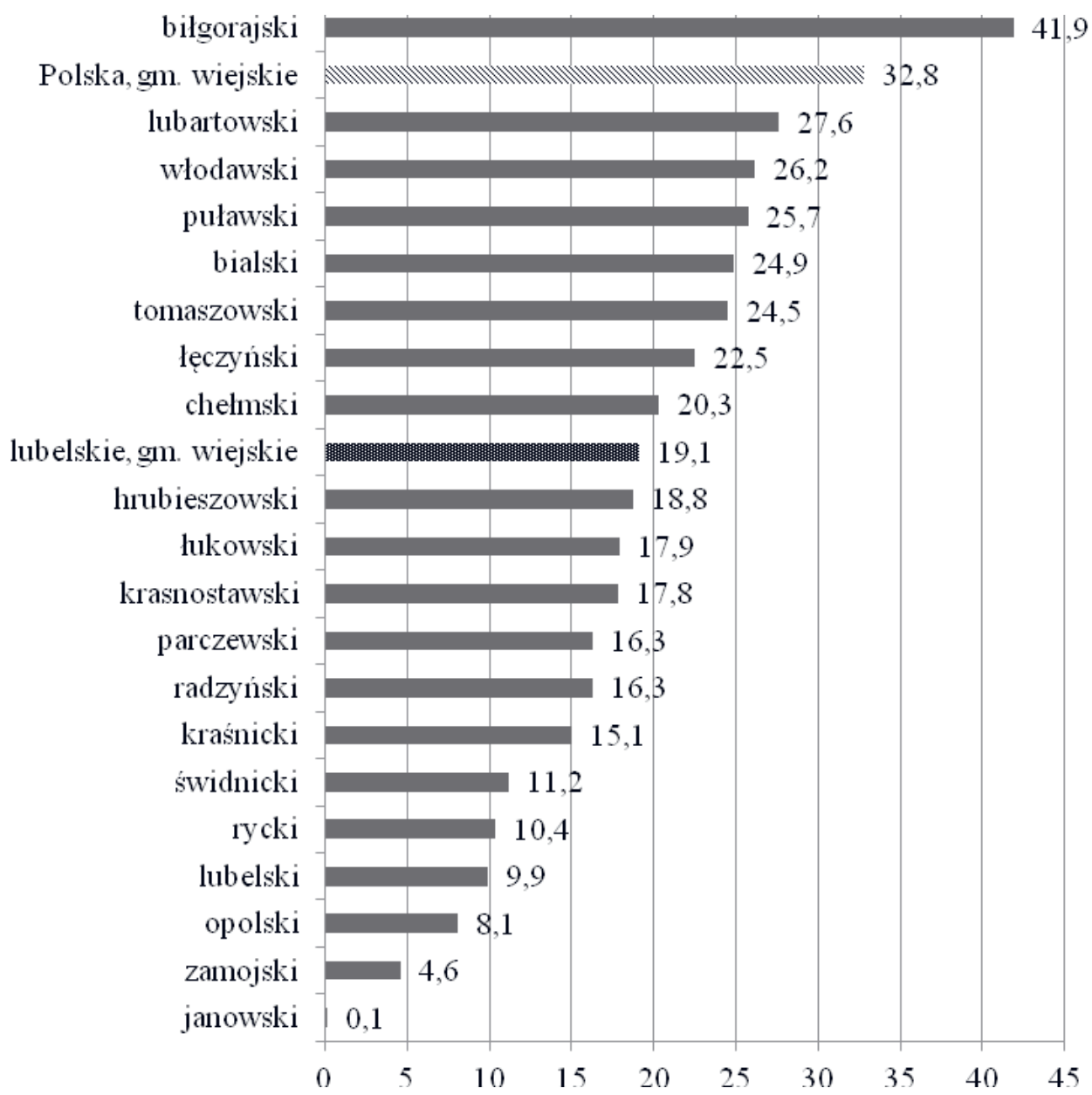

Rysunek 7. Udział mieszkańców korzystających z sieci kanalizacyjnej w ogólnej liczbie ludności w gminach wiejskich według powiatów w 2013 r. (\%)

Źródło: opracowanie własne na podstawie danych BDL GUS.

Kolejne trzy wskaźniki odnoszą się bezpośrednio do jakości życia mieszkańców gminy i stanowią pośrednio odwzorowanie jej potencjału gospodarczego 
(zamożność gminy - por. Szlachta i in. 2009). Jeden z nich to powierzchnia użytkowa mieszkań w przeliczeniu na 1 mieszkańca w gminach wiejskich (rysunek 8). W 2013 roku aż w trzynastu powiatach województwa lubelskiego powierzchnia ta przekraczała średnią krajową wynoszącą $27,5 \mathrm{~m}^{2}$. Najwięcej, bo $31,1 \mathrm{~m}^{2}$ przypadało na mieszkańca w powiatach krasnostawskim i lubelskim. Najmniej - w powiatach janowskim (26) i łukowskim $(25,5)$.

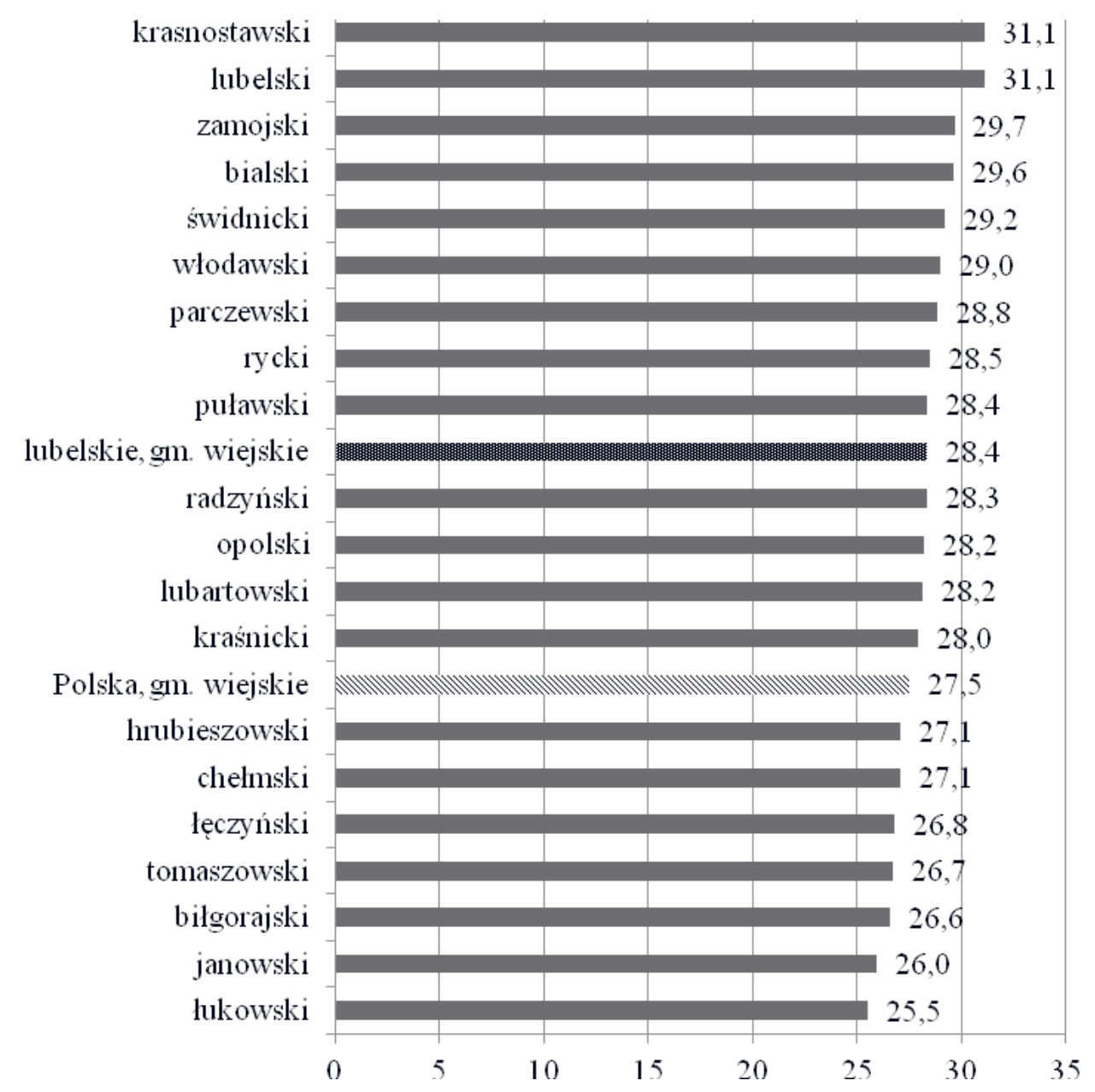

Rysunek 8. Powierzchnia użytkowa mieszkań na 1 mieszkańca w gminach wiejskich według powiatów w $2013 \mathrm{r}$. $\left(\mathrm{m}^{2}\right)$

Źródło: opracowanie własne na podstawie danych BDL GUS.

O atrakcyjności oraz zaawansowaniu rozwojowym gminy może świadczyć udział gruntów zabudowanych i zurbanizowanych w powierzchni ogólnej 
gminy. W 2014 roku gminy wiejskie w powiecie janowskim cechował najniższy udział takich gruntów ( $2 \%$ powierzchni gmin) - dwukrotnie niższy niż na poziomie krajowym oraz w powiatach świdnickim i łęczyńskim (rysunek 9). Przeciętna wartość wskaźnika dla województwa lubelskiego wynosiła 2,9\%.

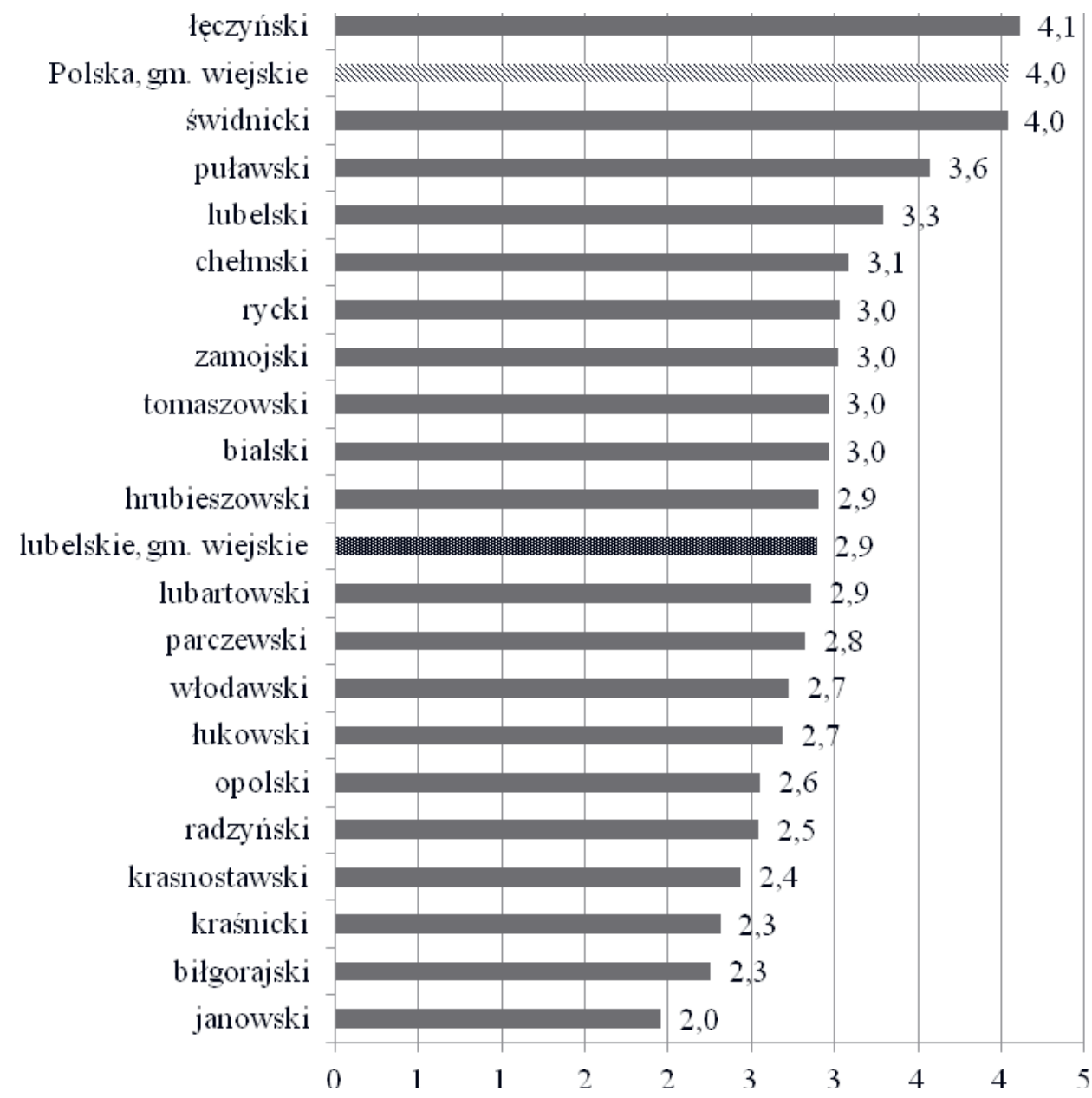

Rysunek 9. Udział gruntów zabudowanych i zurbanizowanych w ogólnej powierzchni w gminach wiejskich według powiatów w 2014 r. (\%)

Źródło: opracowanie własne na podstawie danych BDL GUS.

Kolejnym czynnikiem rozwoju gospodarczego, poddanym analizie, są obszary prawnie chronione. Jak wynika z badań (Kobyliński 2001, Grzebyk 2003: 296-297, Kutkowska 2007, Pomianek 2010), obszary te mogą stanowić 
zarówno ograniczenie rozwoju, z uwagi na przepisy ochrony środowiska, jak i szansę rozwoju przedsiębiorstw. Tam, gdzie rozwój przemysłu nie jest możliwy, szans dla rozwoju przedsiębiorczości upatruje się mikro i małej przedsiębiorczości, tak ważnej dla lokalnych społeczności, a w szczególności w turystyce wiejskiej i agroturystyce, rozwijającej się na bazie obszarów przyrodniczo cennych. Zauważa się także, iż samorządy takich gmin w większym stopniu zdane są na własne siły oraz na konieczność racjonalnego wykorzystania potencjału rozwojowego. Dla ekonomistów, władz samorządowych, a często także dla społeczności lokalnych, wyznaczanie tych obszarów wiąże się z poczuciem zagrożenia dla rozwoju lokalnego. Przyczyn takiego postrzegania tej formy ochrony przyrody należy według Grzebyk (2008: s. 21) upatrywać przede wszystkim w niewystarczającym zakresie akcji informacyjnej oraz w zaniedbaniu konsultacji społecznych. W celu rozwiązania należy poszukiwać kompromisu, zapewnić odpowiednie wsparcie administracji rządowej oraz podnosić świadomość ekologiczną mieszkańców. Stąd też wspieranie rozwoju agroturystyki jest wielostronnie uzasadnione, jako że umożliwia promowanie terenów mniej znanych, choć nie mniej cennych przyrodniczo i kulturowo, przy wykorzystaniu istniejących zasobów gospodarstw, nie wymaga zbyt dużych inwestycji związanych z uruchomieniem działalności oraz daje możliwość rozproszenia, a tym samym zmniejszenia zagrożeń natury ekologicznej, co jest szczególnie istotne na obszarach przyrodniczo cennych (Baranowska-Janota, Korzeniak 1991: 14). Rolniczy charakter województwa lubelskiego stwarza szczególnie dogodne warunki do kreowania dodatkowego dochodu w oparciu o walory przyrodnicze, generowania nowych miejsc pracy, reaktywowania rzemiosła oraz produkcji żywności ekologicznej. Warto zauważyć, iż mali przedsiębiorcy nie wskazują jednoznacznie na trudności przy uruchamianiu i prowadzeniu działalności, wynikające z restrykcji związanych z obszarami prawnie chronionymi. Główną barierę stanowi niedobór środków finansowych. Natomiast w grupie czynników sprzyjających rozwojowi przedsiębiorczości wymienia się promocję regionu, jakość produktów oraz popyt na usługi turystyczne (Grzebyk 2004: 170-171). W analizie gmin wiejskich województwa lubelskiego zakwalifikowano więc obszary przyrodniczo chronione jako stymulantę rozwoju gospodarczego.

W 2014 r. parki krajobrazowe i narodowe, rezerwaty oraz pozostałe obszary chronione przyrodniczo zajmowały w województwie lubelskim przeciętnie $22,6 \%$ (średnia krajowa to $33,5 \%$ ). Jak wynika z rysunku 10 , najwyższe udziały charakteryzowały powiaty: janowski $(63 \%)$, opolski $(49,6 \%)$, chełmski $(42,6 \%)$, włodawski $(41,4 \%)$ i puławski $(34,5 \%)$. Na końcu listy znalazły się powiaty: tomaszowski $(8,5 \%)$, biłgorajski $(8 \%)$ i radzyński $(1 \%)$. 


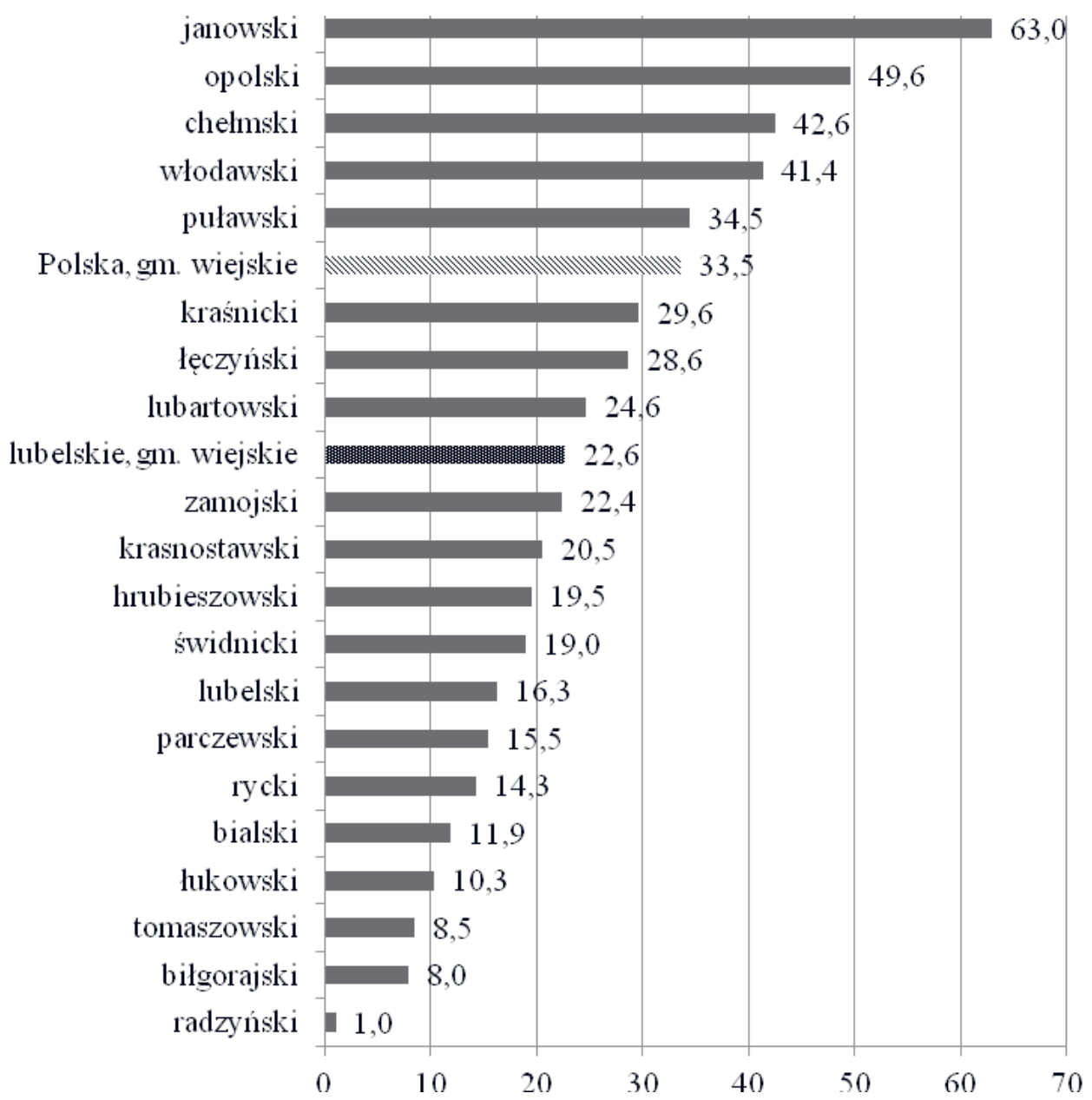

Rysunek 10. Udział powierzchni obszarów prawnie chronionych w ogólnej powierzchni w gminach wiejskich według powiatów w 2014 r. (\%)

Źródło: opracowanie własne na podstawie danych BDL GUS.

Ostatnim analizowanym wskaźnikiem jest poziom dochodów własnych gminy w przeliczeniu na jednego mieszkańca. W roku 2014 najwyższe dochody cechowały gminy wiejskie powiatu łęczyńskiego (przeciętnie 1794 zł). Była to wartość o ponad 370 zł wyższa niż średnia krajowa, prawie dwukrotnie wyższa od średniej wojewódzkiej i ponad 2,5 krotnie wyższa od wartości zamykających listę (powiaty opolski i janowski). Szczegóły przedstawiono na rysunku 11. 


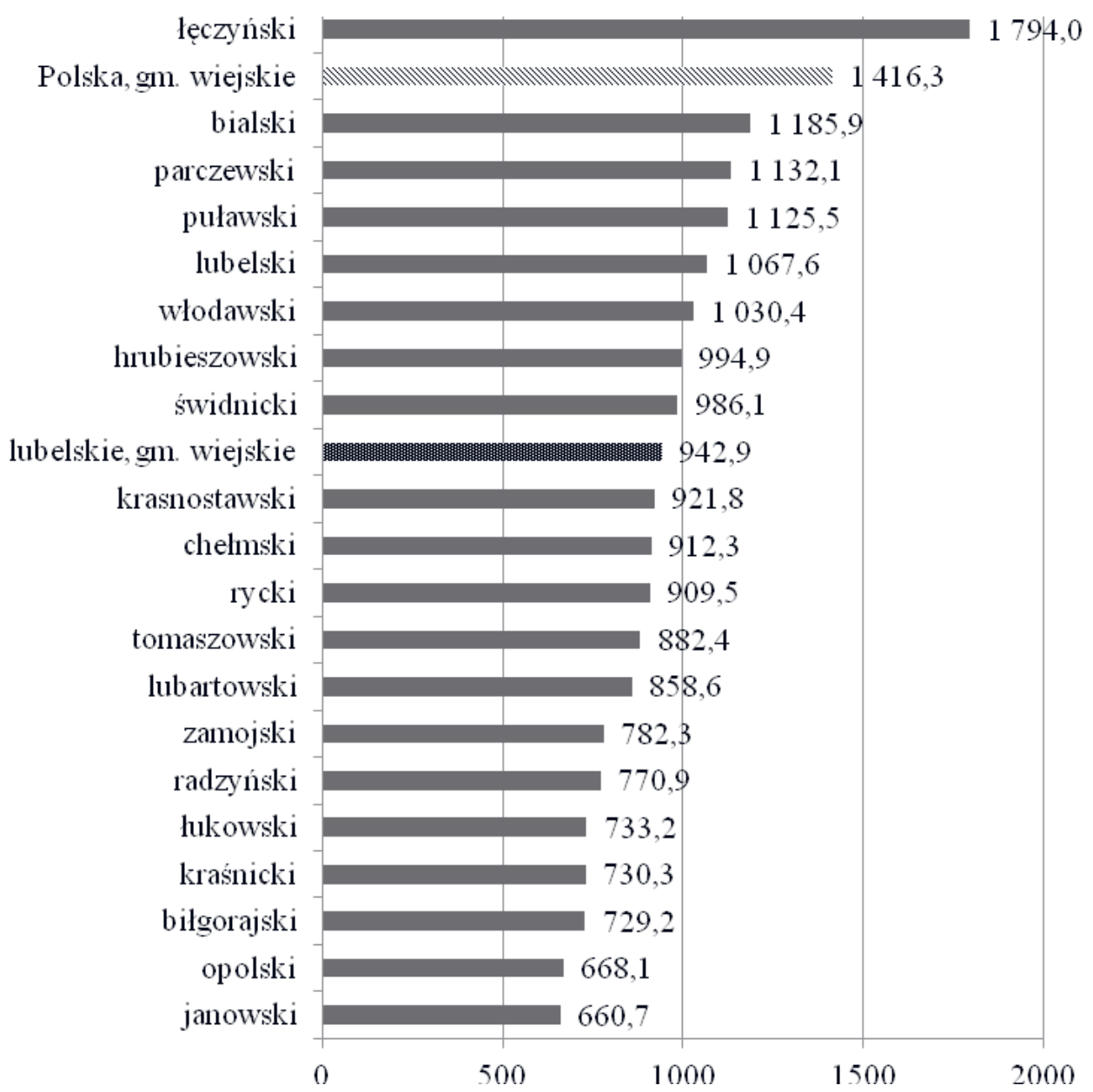

Rysunek 11. Dochody własne budżetu gminy na 1 mieszkańca w gminach wiejskich według powiatów w 2014 r. (zł)

Źródło: opracowanie własne na podstawie danych BDL GUS. 


\section{ZRÓŻNICOWANIE ROZWOJOWE GMIN WIEJSKICH}

W celu oceny poziomu rozwoju gospodarczego gmin wiejskich w województwie lubelskim dokonano doboru zmiennych do konstrukcji wskaźnika syntetycznego. Spośród opisanych powyżej cech wybrano osiem spełniających poniższe warunki:

- kompletność danych;

- wskaźnik zmienności przekraczający 0,10 ;

- brak nadmiernego skorelowania zmiennych.

Wybrany zestaw zmiennych przedstawiono w tabeli 1 .

Tabela 1

Zmienne diagnostyczne przyjęte do oceny poziomu rozwoju gospodarczego gmin wiejskich w województwie lubelskim

\begin{tabular}{|c|c|c|}
\hline Symbol & Zmienna & Typ \\
\hline$X_{1}$ & $\begin{array}{l}\text { Liczba podmiotów gospodarczych zarejestrowanych w REGON } \\
\text { na } 1000 \text { mieszkańców }\end{array}$ & stymulanta \\
\hline$X_{2}$ & $\begin{array}{l}\text { Udział bezrobotnych zarejestrowanych wśród ludności w wieku } \\
\text { produkcyjnym (\%) }\end{array}$ & destymulanta \\
\hline$X_{3}$ & $\begin{array}{c}\text { Udział mieszkańców korzystających z sieci wodociągowej w } \\
\text { ogólnej liczbie ludności (\%) }\end{array}$ & stymulanta \\
\hline$X_{4}$ & $\begin{array}{l}\text { Udział mieszkańców korzystających z sieci kanalizacyjnej w } \\
\text { ogólnej liczbie ludności (\%) }\end{array}$ & stymulanta \\
\hline$X_{5}$ & Powierzchnia użytkowa mieszkań na 1 mieszkańca $\left(\mathrm{m}^{2}\right)$ & stymulanta \\
\hline$X_{6}$ & $\begin{array}{l}\text { Udział gruntów zabudowanych i zurbanizowanych w ogólnej } \\
\text { powierzchni gminy (\%) }\end{array}$ & stymulanta \\
\hline$X_{7}$ & $\begin{array}{l}\text { Udział powierzchni obszarów prawnie chronionych w ogólnej } \\
\text { powierzchni gminy }(\%)\end{array}$ & stymulanta \\
\hline$X_{8}$ & Dochody własne budżetu gminy na 1 mieszkańca (zł) & stymulanta \\
\hline
\end{tabular}

Źródło: opracowanie własne na podstawie danych BDL GUS.

Wśród 29 gmin o wysokim poziomie rozwoju gospodarczego, 6 było usytuowanych w powiecie puławskim, po $5 \mathrm{w}$ powiatach bialskim i lubelskim, a kolejne $2 \mathrm{w}$ powiecie łęczyńskim. Po 2 gminy leżały w granicach powiatów: lubartowskiego, parczewskiego i włodawskiego. Pozostałe należały do powiatów: chełmskiego, ryckiego, świdnickiego i zamojskiego (tabela 2). Ranking otworzyła gmina Terespol (powiat bialski). Wszystkie gminy wiejskie powiatu lubelskiego znalazły się w pierwszej dziesiątce, zajmując pozycje od 3. do 7. 
Tabela 2

Gminy wiejskie województwa lubelskiego o wysokim poziomie rozwoju gospodarczego

\begin{tabular}{|c|c|c|c|c|c|c|c|}
\hline Miejsce & $\begin{array}{c}\text { Gmina } \\
\text { wiejska }\end{array}$ & Powiat & $\begin{array}{c}\text { Wartość } \\
\text { miernika }\end{array}$ & Miejsce c.d. & $\begin{array}{c}\text { Gmina } \\
\text { wiejska }\end{array}$ & Powiat & $\begin{array}{c}\text { Wartość } \\
\text { miernika }\end{array}$ \\
\hline 1 & Terespol & bialski & 0,5089 & 16 & Zalesie & bialski & 0,2806 \\
\hline 2 & Puchaczów & łęczyński & 0,5082 & 17 & Włodawa & włodawski & 0,2800 \\
\hline 3 & Jastków & lubelski & 0,3871 & 18 & Baranów & puławski & 0,2799 \\
\hline 4 & Wólka & lubelski & 0,3750 & 19 & $\begin{array}{c}\text { Janów } \\
\text { Podlaski }\end{array}$ & bialski & 0,2767 \\
\hline 5 & Niemce & lubelski & 0,3739 & 20 & Markuszów & puławski & 0,2758 \\
\hline 6 & Głusk & lubelski & 0,3645 & 21 & Urszulin & włodawski & 0,2708 \\
\hline 7 & Konopnica & lubelski & 0,3569 & 22 & Wisznice & bialski & 0,2697 \\
\hline 8 & Końskowola & puławski & 0,3285 & 23 & Mełgiew & świdnicki & 0,2661 \\
\hline 9 & Ludwin & łęczyński & 0,2975 & 24 & Janowiec & puławski & 0,2550 \\
\hline 10 & Puławy & puławski & 0,2960 & 25 & Kurów & puławski & 0,2516 \\
\hline 11 & Cyców & łęczyński & 0,2901 & 26 & Zamość & zamojski & 0,2511 \\
\hline 12 & Lubartów & lubartowski & 0,2897 & 27 & Stężyca & rycki & 0,2508 \\
\hline 13 & Piszczac & bialski & 0,2853 & 28 & Podedwórze & parczewski & 0,2504 \\
\hline 14 & Uścimów & lubartowski & 0,2832 & 29 & Sosnowica & parczewski & 0,2500 \\
\hline 15 & Chełm & chełmski & 0,2825 & & & & \\
\hline
\end{tabular}

Źródło: opracowanie własne na podstawie danych BDL GUS.

Do grupy o niskim poziomie rozwoju gospodarczego zakwalifikowano 22 gminy wiejskie. Dominowały jednostki z powiatu zamojskiego (5), janowskiego (3) i lubelskiego (3). Z powiatów kraśnickiego i radzyńskiego do tej grupy zaliczono po 2 gminy. Pozostałe pochodziły z powiatów: bialskiego, biłgorajskiego, chełmskiego, hrubieszowskiego, krasnostawskiego, łukowskiego i ryckiego. Przedstawiony ranking zamykają gminy: Gościeradów (powiat kraśnicki), Miączyn (powiat zamojski) i Dzwola (powiat janowski).

Tabela 3

Gminy wiejskie województwa lubelskiego o niskim poziomie rozwoju gospodarczego

\begin{tabular}{|c|c|c|c|c|c|c|c|}
\hline Miejsce & $\begin{array}{c}\text { Gmina } \\
\text { wiejska }\end{array}$ & Powiat & $\begin{array}{c}\text { Wartość } \\
\text { miernika }\end{array}$ & Miejsce c.d. & $\begin{array}{c}\text { Gmina } \\
\text { wiejska }\end{array}$ & Powiat & $\begin{array}{c}\text { Wartość } \\
\text { miernika }\end{array}$ \\
\hline 149 & $\begin{array}{c}\text { Ulan- } \\
\text { Majorat }\end{array}$ & radzyński & 0,0832 & 160 & Chrzanów & janowski & 0,0697 \\
\hline 150 & Borki & radzyński & 0,0828 & 161 & Grabowiec & zamojski & 0,0689 \\
\hline 151 & Wojciechów & lubelski & 0,0822 & 162 & Godziszów & janowski & 0,0620 \\
\hline
\end{tabular}


Tab. 3 (cd.)

\begin{tabular}{|c|c|c|c|c|c|c|c|}
\hline Miejsce & $\begin{array}{c}\text { Gmina } \\
\text { wiejska }\end{array}$ & Powiat & $\begin{array}{c}\text { Wartość } \\
\text { miernika }\end{array}$ & Miejsce c.d. & $\begin{array}{c}\text { Gmina } \\
\text { wiejska }\end{array}$ & Powiat & $\begin{array}{c}\text { Wartość } \\
\text { miernika }\end{array}$ \\
\hline 152 & Adamów & zamojski & 0,0820 & 163 & $\begin{array}{c}\text { Wojciesz- } \\
\text { ków }\end{array}$ & tukowski & 0,0593 \\
\hline 153 & Uchanie & $\begin{array}{c}\text { hrubieszow- } \\
\text { ski }\end{array}$ & 0,0820 & 164 & Łabunie & zamojski & 0,0575 \\
\hline 154 & Goraj & biłgorajski & 0,0802 & 165 & Nowodwór & rycki & 0,0540 \\
\hline 155 & $\begin{array}{c}\text { Trzydnik } \\
\text { Duży }\end{array}$ & kraśnicki & 0,0791 & 166 & Rudnik & $\begin{array}{c}\text { krasnostaw- } \\
\text { ski }\end{array}$ & 0,0518 \\
\hline 156 & Nielisz & zamojski & 0,0791 & 167 & Drelów & bialski & 0,0346 \\
\hline 157 & Ruda-Huta & chełmski & 0,0776 & 168 & $\begin{array}{c}\text { Gościera- } \\
\text { dów }\end{array}$ & kraśnicki & 0,0288 \\
\hline 158 & Zakrzew & lubelski & 0,0718 & 169 & Miączyn & zamojski & 0,0229 \\
\hline 159 & Borzechów & lubelski & 0,0711 & 170 & Dzwola & janowski & 0,0000 \\
\hline
\end{tabular}

Źródło: opracowanie własne na podstawie danych BDL GUS.

W powiatach bialskim i lubelskim można zauważyć znaczne zróżnicowanie w poziomie rozwoju gospodarczego gmin. Do klasy o wysokim poziomie rozwoju należała tam co trzecia gmina wiejska. Nie zabrakło także gmin z klasy o niskim poziomie rozwoju, położonych peryferyjnie w odniesieniu do miast powiatowych. Odwrotną sytuację można zaobserwować w powiecie zamojskim, gdzie co drugą gminę wiejską cechował niski poziom rozwoju gospodarczego, a tylko jedna należała do klasy o wysokim poziomie rozwoju. Powiat puławski zasługuje na szczególną uwagę. Spośród ośmiu gmin wiejskich aż sześć zakwalifikowano jako wysoko rozwinięte, a pozostałe uplasowały się na relatywnie niedalekich pozycjach 35. (Wąwolnica) i 52. (Żyrzyn). Oprócz powiatu puławskiego, także w powiatach: lubartowskim, łęczyńskim, parczewskim, świdnickim i włodawskim gminy były kwalifikowane do grup o wysokim lub o średnim poziomie rozwoju. Z powiatów chełmskiego i ryckiego w skrajnych klasach znalazło się po jednej gminie wiejskiej. Wszystkie gminy wiejskie z powiatów opolskiego i tomaszowskiego zostały zakwalifikowane do klasy o średnim poziomie rozwoju. W zakres powiatów: biłgorajskiego, hrubieszowskiego, janowskiego, kraśnickiego, krasnostawskiego, łukowskiego i radzyńskiego, wchodziły wyłącznie jednostki o średnim i niskim poziomie rozwoju.

Na rysunku 12. widoczny jest lekko zarysowany półpierścień wyznaczony przez gminy wiejskie o wysokim poziomie rozwoju gospodarczego. Były to głównie gminy sąsiadujące lub znajdujące się w promieniu oddziaływania ważnych ośrodków miejskich, tj. Lublina, Puław, Łęcznej, Włodawy i Terespola. W południowej części województwa wysokim rozwojem charakteryzowały się gminy podmiejskie Chełm i Zamość. Gminy wiejskie o niskim poziomie rozwoju rozmieszczone były głównie w dwóch poprzecznych pasach, na północy i na południu województwa. W pasie 
północnym znalazły się gminy: Nowodwór, Wojcieszków, Ulan-Majorat, Borki i Drelów. W pasie południowym rozmieszczonych było czternaście gmin: Gościeradów, Trzydnik Duży, Godziszów, Chrzanów, Zakrzew, Dzwola, Goraj, Rudnik, Nielisz, Adamów, Łabunie, Miączyn, Grabowiec oraz Uchanie.

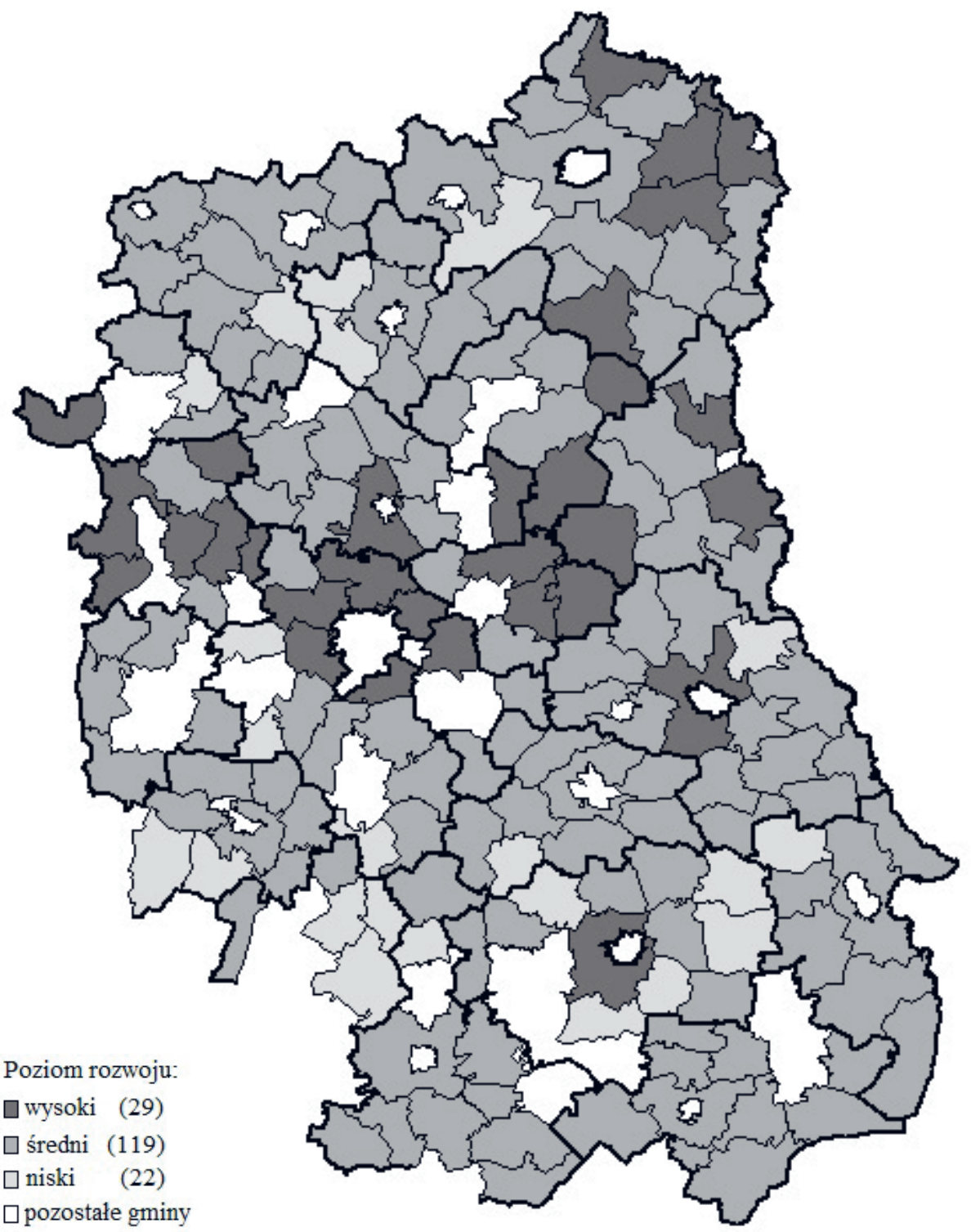

Rysunek 12. Rozkład przestrzenny gmin wiejskich województwa lubelskiego pod względem poziomu rozwoju gospodarczego

Źródło: opracowanie własne na podstawie danych BDL GUS. 
Porównanie średnich wartości analizowanych zmiennych według grup gmin (tabela 4) pozwala zauważyć istotne różnice między klasami rozwojowymi jednostek. Gminy wiejskie województwa lubelskiego, o wysokim poziomie rozwoju gospodarczego, pozostają w pewnym dystansie od średnich wartości krajowych w zakresie liczby podmiotów gospodarczych, stopnia wykorzystania sieci kanalizacyjnej czy też udziału obszarów chronionych przyrodniczo. Niemniej jednak, w tym porównaniu wypadają dosyć korzystnie pod względem liczby bezrobotnych, liczby korzystających z wodociągów, dochodów własnych gminy oraz powierzchni użytkowej mieszkań.

Tabela 4

Średnie wartości analizowanych zmiennych według grup gmin

\begin{tabular}{|c|c|c|c|c|c|c|c|c|}
\hline \multirow{2}{*}{$\begin{array}{c}\text { Gminy } \\
\text { wiejskie }\end{array}$} & $X_{1}$ & $X_{2}$ & $X_{3}$ & $X_{4}$ & $X_{5}$ & $X_{6}$ & $X_{7}$ & $X_{8}$ \\
\cline { 2 - 9 } poziom rozwoju \\
\hline \multicolumn{8}{|c|}{ 'rednie wartości zmiennych } \\
\hline wysoki & 65,28 & 8,20 & 78,00 & 27,75 & 29,64 & 4,04 & 1533,81 & 25,37 \\
\hline średni & 50,32 & 9,65 & 73,72 & 19,76 & 28,25 & 2,71 & 850,16 & 23,59 \\
\hline niski & 45,33 & 9,90 & 52,75 & 4,03 & 27,23 & 2,34 & 665,29 & 13,65 \\
\hline \multicolumn{7}{|c|}{ województwo lubelskie } \\
\hline razem & 52,23 & 9,44 & 71,73 & 19,09 & 28,35 & 2,89 & 942,86 & 22,60 \\
\hline \multicolumn{7}{|c|}{ Polska } \\
\hline razem & 73,50 & 8,60 & 76,70 & 32,80 & 27,50 & 4,04 & 1416,34 & 33,55 \\
\hline
\end{tabular}

Źródło: opracowanie własne na podstawie danych BDL GUS.

Jak wynika z innych badań autorki (Pomianek 2014: 162-169), gminy wiejskie usytuowane wzdłuż krajowych szlaków komunikacyjnych charakteryzują się wyższym poziomem konkurencyjności w porównaniu z pozostałymi obszarami (m.in. Międzyrzec Podlaski, Biała Podlaska, Terespol, Wisznice i Włodawa). Wpływ dostępności komunikacyjnej i transportowej na potencjał ekonomiczny jednostek terytorialnych (na przykładzie różnej wielkości miast) podkreśla także Jakubowski (2011: 116-131). Przeprowadzone analizy potwierdzają korzystny wpływ szlaków komunikacyjnych oraz bliskości ważniejszych ośrodków miejskich na poziom rozwoju gospodarczego gmin wiejskich w województwie lubelskim. 


\section{PODSUMOWANIE}

Największe wyzwania gmin wiejskich o niskim poziomie rozwoju (w odniesieniu do średniej krajowej) związane są z niskim udziałem mieszkańców korzystających z sieci kanalizacyjnej oraz niskimi dochodami własnymi budżetu gminy per capita. Władze lokalne powinny zadbać przede wszystkim o poprawę stanu infrastruktury technicznej, co spowoduje podniesienie atrakcyjności terenów i przyciągnięcie nowych przedsiębiorców, stworzenie nowych miejsc pracy i poprawę jakości życia mieszkańców. Dużą szansę samorządy powinny upatrywać w dostępnych funduszach unijnych, niedawno rozpoczętej perspektywie finansowej 2014-2020. Jednocześnie ważna jest kampania informacyjna, przedstawiająca obecne (w tym środowiskowe) i przyszłe walory lokalizacji działalności gospodarczej i zamieszkania w gminie.

\section{BIBLIOGRAFIA}

Baranowska-Janota M., Korzeniak G. (1991), Zasady turystycznego użytkowania i ochrony parków krajobrazowych, Instytut Gospodarki Przestrzennej i Komunalnej, Kraków.

Dijkstra L., Poelman H. (2008), Remote Rural Regions. How proximity to a city influences the performance of rural regions, „Regional Focus”, 1/2008, European Commission, Regional Policy, http://ec.europa.eu/regional_policy/sources/docgener/focus/2008_01_rural.pdf (dostęp: 23.05.2014).

Generalna Dyrekcja Dróg Krajowych i Autostrad https:/www.gddkia.gov.pl/userfiles/articles/s/ siec-drog-krajowych_2542/mapa_2015_siec\%20drog.jpg (dostęp: 29.07.2015)

Grzebyk B. (2003), Szanse i ograniczenia rozwoju przedsiębiorczości na obszarach prawnie chronionych (na przykładzie gminy Baligród), [w:] Czudec A. (red.): Regionalne uwarunkowania ekonomicznego rozwoju rolnictwa i obszarów wiejskich, tom 2, Wydawnictwo Uniwersytetu Rzeszowskiego, Rzeszów, s. 296-297

Grzebyk B. (2004), Rozwój przedsiębiorczości na obszarach prawnie chronionych (na przyktadzie powiatu bieszczadzkiego), maszynopis rozprawy doktorskiej pod kierunkiem prof. dr hab. B. Klepackiego, Szkoła Główna Gospodarstwa Wiejskiego, Wydział Ekonomiczno-Rolniczy.

Grzebyk B. (2008), Rozwój działalności pozarolniczej na terenach przyrodniczo cennych, „Wieś Jutra", 10 (123).

Hellwig Z. (1986), Zastosowanie metody taksonomicznej do typologicznego podziału krajów ze względu na poziom rozwoju i strukturę kwalifikowanych kadr, „Przegląd Statystyczny”, nr 4.

Jakubowski A. (2011), Dostęność komunikacyjna i transportowa miast w województwie lubelskim, [w:] Bronisz U. (red.), Potencjal ekonomiczny miast w województwie lubelskim w latach 2000-2010, Urząd Statystyczny w Lublinie, s. 116-131.

Kalinowski T. (2007), Sukces rozwojowy polskich województw, Instytut Badań nad Gospodarką Rynkową, Gdańsk.

Kiniorska I. (2014), Potencjat rozwojowy obszarów wiejskich woj. świętokrzyskiego a polityka spójności w: Kamińska W., Heffner K. (red.), Polityka spójności UE a rozwój obszarów wiejskich, Stare problemy i nowe wyzwania, ,Studia KPZK PAN”, t. 156. 
Kobyliński R. (2001), Wybrane problemy rozwoju przedsiębiorczości na obszarach chronionych, [w:] Kłodziński M. (red.) Gospodarka, człowiek, środowisko na obszarach wiejskich, IRWiR PAN, Warszawa.

Krakowiak-Bal A. (2006), Potencjat gospodarczy gmin przygranicznych Polski poludniowej, „Infrastruktura i Ekologia Terenów Wiejskich", nr 2/2, s. 149-158.

Kudłacz T. (1999), Programowanie rozwoju regionalnego, Wydawnictwo Naukowe PWN, Warszawa.

Kutkowska B. (2007), Kierunki rozwoju obszarów wiejskich zlokalizowanych na terenach o dużych walorach przyrodniczych, „Wieś i Rolnictwo”, nr 3 (136), s. 109-130.

Milczarek D. (2005a), Potencjat Unii Europejskiej w stosunkach międzynarodowych (część 1), „Studia Europejskie", nr 1.

Milczarek D. (2005b), Potencjat Unii Europejskiej w stosunkach międzynarodowych (część 2), „Studia Europejskie”, nr 2.

Pomianek I. (2009), Społeczno-ekonomiczne uwarunkowania rozwoju przedsiębiorczości na obszarach wiejskich (na przykładzie województwa warmińsko-mazurskiego), maszynopis rozprawy doktorskiej pod kierunkiem prof. dr hab. J. Sawickiej, Szkoła Główna Gospodarstwa Wiejskiego, Wydział Nauk Ekonomicznych.

Pomianek I. (2014), Wybrane przejawy konkurencyjności wiejskich obszarów peryferyjnych na przyktadzie podregionu bialskiego, „Marketing i Rynek”, R. 21, nr 10, s. 162-169.

Reichel M. (2003), Istota i czynniki rozwoju regionalnego w: Fudaliński J. (red.), Wybrane zagadnienia rozwoju regionalnego i zarządzania organizacjami, Państwowa Wyższa Szkoła Zawodowa, Nowy Sącz.

Szlachta J., Dziemianowicz W., Szmigiel K., Nowicka P. (2009), Potencjat rozwojowy gmin województwa lubelskiego, „Barometr Regionalny', nr 2(16), s. 17-27.

Wójcik P. (2011), Analiza wskaźników społeczno-ekonomicznych dla gmin w Polsce, Wybór jednostek do badania ankietowego, [w:] Okoń-Horodyńska E. (red.), Potencjał rozwojowy gmin $w$ Polsce, Wydawnictwo Uniwersytetu Warszawskiego, Warszawa.

\title{
Iwona Pomianek
}

\section{CHARACTERISTICS OF ECONOMIC POTENTIAL AND SPATIAL DEVELOPMENT DIFFERENTIATION OF RURAL COMMUNES IN LUBELSKIE VOIVODSHIP}

\begin{abstract}
The paper presents characteristics of the economic potential of territorial units at LAU-2 level. The analysis included 170 rural communes in Lubelskie Voivodship. Based on eight variables, Hellwig's taxonomic meter enabled grouping the communes according to their level of economic development. 29 of them were distinguished as relatively highly developed, whereas 22 communes represented a low level of development. Units with high level of development were distributed mainly in following districts: Bialski, Lubelski, Lukowski and Leczynski. The weakest communes were focused in Janowski, Zamojski and Lubelski districts. It may be noted that the geographical location of rural communes in lubelski district has a significant influence on their differentiation and development. The communes surrounding the capital of the province - Lublin - represented the group of high development level, while communes located peripherally were qualified to the weakest group.
\end{abstract}

Keywords: economic development, economic potential, rural areas, Eastern Poland. 